\title{
Composition and population dynamics of planktonic bacteria and bacterivorous flagellates in seawater chemostat cultures
}

\author{
Ramon Massana ${ }^{1}$, Klaus Jürgens ${ }^{2,3, *}$ \\ ${ }^{1}$ Institut de Ciències del Mar, CSIC, Passeig Marítim de la Barceloneta 37-49, 08003 Barcelona, Catalonia, Spain \\ ${ }^{2}$ Max Planck Institute for Limnology, Department of Physiological Ecology, PO Box 165, 24302 Plön, Germany
}

${ }^{3}$ Present address: Baltic Sea Research Institute, Seestrasse 15, 18119 Rostock, Germany

\begin{abstract}
We studied the effects of protist predation on the composition and morphological structure of a marine bacterioplankton assemblage. A mixed bacterial assemblage $(0.6 \mu \mathrm{m}$ filtered North Sea inoculum) was cultivated with unamended seawater as medium in four 1-stage chemostats. After the establishment of a bacterial community, 2 of the chemostats received a $2 \mu \mathrm{m}$ filtered seawater inoculum which enabled the development of heterotrophic nanoflagellates (HNF). The dynamics of bacterial and protist community composition in the chemostat cultures was followed by terminalrestriction fragment length polymorphism (T-RFLP) and denaturing gradient gel electrophoresis (DGGE). These fingerprinting techniques revealed that continuous cultivation with unsupplemented seawater altered the bacterial community composition compared to the inoculum. Fluorescent in situ hybridisation (FISH) analysis showed that the bacterial assemblages in the chemostats were dominated by $\gamma$-Proteobacteria, particularly of the genus Alteromonas. Despite this shift, the overall richness of bacteria in the chemostats remained relatively high with up to 30 different operational taxonomic units (OTUs). HNF exerted efficient grazing control on the bacterial communities during $3 \mathrm{wk}$ of cultivation and reduced bacterial biomass to approximately $10 \%$ of that in the predator-free chemostats. Only a modest development of grazing-resistant bacteria occurred, which contrasts with previously published chemostat experiments with freshwater microbial communities. T-RFLP and DGGE analyses also revealed that protist grazing did not result in significant changes in bacterial community composition. However, both fingerprinting techniques showed a relatively high richness (up to 15 different OTUs) and an ongoing succession within the protist assemblage, which might be one explanation for only low feed-back effects and low appearance of grazing-resistance in the predation-controlled bacterial community.
\end{abstract}

KEY WORDS: Protist predation - Bacterial community composition · Heterotrophic nanoflagellates · Population dynamics $\cdot$ Chemostat cultures $\cdot$ T-RFLP $\cdot$ DGGE $\cdot$ FISH

\section{INTRODUCTION}

Predation by heterotrophic and mixotrophic protists is known to be a major controlling factor of bacterial abundance in planktonic systems (reviewed by Strom 2000). Whereas many field studies in marine and freshwater systems have aimed at quantifying bacterial grazing mortality, more recently, the qualitative aspects of bacteria-protists interactions have also been emphasised. Selective protozoan grazing can have a significant impact on the size structure and taxonomic composition of bacterial assemblages (see reviews by Jürgens \& Güde 1994, Hahn \& Höfle 2001, Jürgens \& Matz 2002). This is particularly the case when grazing is dominated by heterotrophic nanoflagellates (HNF), a functional group of wide phylogenetic diversity, which are adapted to feed on suspended bacteria and are generally the major bacterivores in pelagic systems (Fenchel 1986).

Both very small and large bacterial cells gain some size refuge against HNF (Güde 1989), which can be mediated by phenotypic plasticity of certain bacterial 
taxa (Hahn \& Höfle 1999). More recently, some nonmorphological bacterial properties, such as motility and physico-chemical surface characters, have also been found to reduce grazing mortality (Matz et al. 2002). Heterogeneity in bacterial vulnerability towards protist grazers combined with selective predation can result in strong shifts of bacterial community composition. This has been demonstrated by experimental manipulations in which protist grazing pressure was enhanced, either in field enclosure experiments (Jürgens et al. 1999, Šimek et al. 1999) or in laboratory studies with model communities of bacteria and protists (Pernthaler et al. 1997, Šimek et al. 1997). The appearance of high numbers of morphologically predation-resistant bacteria (e.g. filamentous forms or aggregates) in more productive freshwater (Jürgens \& Stolpe 1995, Sommaruga \& Psenner 1995) or coastal marine systems (Havskum \& Hansen 1997) indicates that feed-back mechanisms at the bacterial level are indeed a widespread phenomenon in natural systems and might contribute to a stabilisation of bacterial biomass (Jürgens \& Güde 1994).

We are just beginning to understand some of the underlying mechanisms concerning how the structure of complex bacterial communities is shaped by protist predation. Major new insights have been obtained from the study of microbial model communities in laboratory experiments. Continuous flow systems proved to be particularly useful in order to examine bacteriaprotist interactions as grazing and bacterial growth can be maintained simultaneously under controlled conditions for extended periods. The impact of bacterial grazers has been studied either in 2-stage chemostat systems (Pernthaler et al. 1997, Šimek et al. 1997) where bacteria grown in a first stage are transferred to a second protist stage, or in 1-stage chemostats (Hahn \& Höfle 1999, Matz \& Jürgens 2003) in which bacterial growth medium nurtures a bacteria-protist assemblage. Bacterial feed-back mechanisms are particularly expected in 1-stage systems because of the higher bacterial growth potential which could result in compensation of grazing mortality. The development of inedible bacterial morphologies in response to HNF grazing on a mixed bacterial community in chemostat cultures resulted in shifts of the overall bacterial community structure (Pernthaler et al. 1997, Šimek et al. 1997, Hahn \& Höfle 1999). In these studies, the development of totally or partially inedible bacteria compensated grazing losses and resulted in nearly similar bacterial biomass levels in chemostats with and without grazers.

The potential of bacterial populations or communities to compensate for grazing mortality by the development of inedible forms has been studied nearly exclusively with freshwater model systems, although there are indications that similar mechanisms occur in marine plankton communities. For example, sizedependent HNF feeding efficiency has frequently been demonstrated for marine flagellates (González et al. 1990, 1993) and also the development of resistant bacterial morphologies (filamentous forms) was reported from enclosure experiments with coastal marine water (Havskum \& Hansen 1997, Engström-Öst et al. 2002). However, in general, mechanisms of bacterial adaptation towards predation have not been extensively investigated in marine systems (Strom 2000).

In this study, we intended to use a seawater continuous culture approach, comparing bacterial chemostat cultures with and without protist predators, to study the effects of protist grazing on a growing marine bacterioplankton assemblage. A morphological analysis of the bacterial community was combined with 2 DNA fingerprinting techniques, terminal-restriction fragment length polymorphism (T-RFLP) and denaturing gradient gel electrophoresis (DGGE). These were based on the amplification of the small subunit (SSU) rDNA genes and allowed the examination of the grazing impact and the population dynamics of bacteria and protists.

\section{MATERIALS AND METHODS}

Experimental design. Seawater was collected in the German Bight of the North Sea at a sampling station near the island of Helgoland (max. depth $15 \mathrm{~m}$, salinity $33.6 \%$, temperature $14.2^{\circ} \mathrm{C}$ ). From a depth of $0.5 \mathrm{~m}$, 1001 surface seawater was pumped unfiltered into acid-washed 201 polyethylene containers and then transported back to the laboratory. The seawater was pressure-filtered through a GF/C glass-fiber filter (142 $\mathrm{mm}$ in diameter) and stored at $4^{\circ} \mathrm{C}$ in the dark. This stock of seawater medium was used for the whole experimental period. Inorganic nutrient concentrations were $0.31 \mu \mathrm{M}$ orthophosphate, $0.27 \mu \mathrm{M}$ nitrite, $3.2 \mu \mathrm{M}$ nitrate and $0.67 \mu \mathrm{M}$ ammonium (K. H. Wiltshire, P. Mangelsdorf \& H. Spindler 2001, time series and project data of the Biologische Anstalt Helgoland. available at: www.pangaea.de). For the inocula with micro-organisms, 31 seawater were gravity filtered through a $2 \mu \mathrm{m}$ polycarbonate filter (47 $\mathrm{mm}$, Millipore) and kept in the dark at $16^{\circ} \mathrm{C}$ until use.

Four 1-stage chemostat systems (2 1 conical glass vessels) were set up in a temperature-controlled room at 16 $\pm 0.5^{\circ} \mathrm{C}$ and kept in the dark (except for sampling) to prevent growth of autotrophic organisms. The chemostat inflow reservoir was filled with particle-free seawater, which was filtered 2 times through rinsed and autoclaved cellulose acetate filters $(0.2 \mu \mathrm{m}, 142 \mathrm{~mm}$, Sartorius). The inflow of filtered seawater was con- 
trolled by peristaltic pumps and held constant at a dilution rate of 0.018 to $0.022 \mathrm{~h}^{-1}$ (corresponding to bacterial generation times of 32 to $39 \mathrm{~h}$ ). The vessels were continuously aerated and mixed by slow bubbling with sterile air. The chemostat medium reservoir was sampled every day and checked by epifluorescence microscopy for bacterial growth. When contamination was detected, the reservoir bottle was immediately exchanged for a new, autoclaved one and filled with fresh, filtered medium from the same seawater stock.

For inoculation with bacteria, each chemostat received $200 \mathrm{ml}$ of the $<2 \mu \mathrm{m}$-filtered seawater, additionally filtered by a $47 \mathrm{~mm}$ GF/F filter, before the media flow was turned on. Sampling of the chemostats started when the water level reached $1.5 \mathrm{l}$ and inflow equalled outflow. Bacterial growth was followed for $12 \mathrm{~d}$ before 2 of the chemostats (F1 and F2) received $20 \mathrm{ml}$ of $<2 \mu \mathrm{m}$ filtered seawater in order to allow the development of bacterivorous nanoflagellates. To account for the introduction of new bacteria, the bacterial control chemostats (B1 and B2) received $20 \mathrm{ml}$ of the same water; however, in this case, it had been additionally filtered through a GF/F filter.

Microbial abundance and cell sizes. Subsamples were fixed with formaldehyde ( $2 \%$ final concentration), stained with DAPI and filtered on black $0.2 \mu \mathrm{m}$ polycarbonate filters (Millipore). Bacteria and HNF were enumerated from the same filters in an epifluorescence microscope (Zeiss Axiophot). For selected time points, bacterial cell dimensions were determined from DAPI preparations with an automated image analysis system (SIS) and with image processing comparable to that described in Massana et al. (1997). Between 200 and 500 bacteria were analysed per sample, and cell dimensions (length, width, volume) were calculated from area and cell perimeter according to Algorithm 3 given in Massana et al. (1997), which has been proven to be appropriate for most types of bacteria.

Fluorescent in situ hybridisation (FISH). Subsamples $(50 \mathrm{ml})$ from the chemostats were fixed with formaldehyde ( $2 \%$ final concentration), kept for 2 to $3 \mathrm{~h}$ at $4^{\circ} \mathrm{C}$, then filtered through $0.2 \mu \mathrm{m}$ polycarbonate filters ( $47 \mathrm{~mm}$, Millipore), washed with Millipore water and finally stored at $-20^{\circ} \mathrm{C}$. For hybridisation and DAPI staining on sections of the membrane filters, we followed the protocol of Pernthaler et al. (2001a). We used group-specific Cy3-labelled oligonucleotide probes (Interactiva) targeted to the kingdom Bacteria (EUB), the $\alpha, \beta$ and $\gamma$ subdivisions of the phylum Proteobacteria $(\alpha, \beta$ and $\gamma$-Proteobacteria, ALF, BET and GAM, respectively), and the Cytophaga/Flavobacterium group (CF) (Amann et al. 1995). Additionally, 3 recently described probes for subgroups of the $\gamma$ Proteobacteria, SAR86-1249 (for the SAR 86 cluster), ALT1413 (for Alteromonas spp.) and PSA184 (for
Pseudoalteromonas spp.), were used (Eilers et al. $2000 b)$. Percentages of hybridised cells were obtained from DAPI-stained and hybridised cells which were counted from the same microscopic fields.

Extraction of total DNA. Subsamples for DNA extraction (50 to $100 \mathrm{ml}$ ) were collected on $0.2 \mu \mathrm{m}$ Durapore filters (25 mm, Millipore). The filters were covered with $1 \mathrm{ml}$ lysis buffer (40 mM EDTA, $50 \mathrm{mM}$ Tris- $\mathrm{HCl}, 0.75 \mathrm{M}$ Sucrose) and stored frozen at $-20^{\circ} \mathrm{C}$ until nucleic acid extraction. DNA extraction started by incubating the filters with lysozyme $\left(1 \mathrm{mg} \mathrm{ml}^{-1}\right.$ final concentration) at $37^{\circ} \mathrm{C}$ for $45 \mathrm{~min}$. Then sodium dodecyl sulfate ( $1 \%$ final concentration) and proteinase $\mathrm{K}$ $\left(0.2 \mathrm{mg} \mathrm{ml}^{-1}\right.$ final concentration) were added, and the filters were incubated at $55^{\circ} \mathrm{C}$ for $60 \mathrm{~min}$. The lysate was extracted with an equal volume of phenol-chloroform-isoamyl alcohol (25:24:1), and the residual phenol was removed by extraction with an equal volume of chloroform-isoamyl alcohol (24:1). DNA was further purified, desalted, and concentrated with a Centricon100 concentrator (Millipore). The integrity of the total DNA was checked by agarose gel electrophoresis. The DNA yield was quantified spectrofluorometrically by a Hoechst dye fluorescence assay (Paul \& Myers 1982). Nucleic acid extracts were stored at $-80^{\circ} \mathrm{C}$ until further analysis.

PCR of the small subunit rDNA. About $2 \mathrm{ng}$ of extracted DNA was used as template for the different PCRs. For further analysis by DGGE, the bacterial 16S rDNA-specific primers 341F-GC and 907R (Muyzer \& Smalla 1998) and the eukaryotic 18S rDNA-specific primers Euk1F and Euk516R-GC (Díez et al. 2001a) were used. The PCR mixtures $(50 \mu l)$ contained forward and reverse primers (each at $0.3 \mu \mathrm{M}$ ), each deoxynucleoside triphosphate at $200 \mu \mathrm{M}, 1.25 \mathrm{U}$ of Taq DNA polymerase, and the PCR buffer supplied with the enzyme. The PCR program for the 16S rDNA amplification consisted of an initial denaturation step of $94^{\circ} \mathrm{C}$ for $5 \mathrm{~min}$, followed by 10 touchdown cycles of denaturation at $94^{\circ} \mathrm{C}$ for $1 \mathrm{~min}$, annealing at $65^{\circ} \mathrm{C}$ (decreasing in each cycle by $1^{\circ} \mathrm{C}$ ) for $1 \mathrm{~min}$, and extension at $72^{\circ} \mathrm{C}$ for $3 \mathrm{~min}$. This was followed by another 20 cycles at $94^{\circ} \mathrm{C}$ for $1 \mathrm{~min}, 55^{\circ} \mathrm{C}$ for $1 \mathrm{~min}$ and $72^{\circ} \mathrm{C}$ for 3 min. During the last cycle, the extension step was increased to $5 \mathrm{~min}$. The PCR program for the 18S rDNA amplification consisted of an initial denaturation step of $94^{\circ} \mathrm{C}$ for $2 \mathrm{~min}$, followed by 30 cycles of denaturation at $94^{\circ} \mathrm{C}$ for $30 \mathrm{~s}$, annealing at $56^{\circ} \mathrm{C}$ for $45 \mathrm{~s}$ and extension at $72^{\circ} \mathrm{C}$ for $2 \mathrm{~min}$. During the last cycle, the extension step was increased to $6 \mathrm{~min}$. An aliquot of the PCR product was electrophoresed in a $0.8 \%$ agarose gel and stained with ethidium bromide.

For analysis by T-RFLP, the primers 27F-FAM and 1492R were used for PCR which give approximately a $1500 \mathrm{bp}$ product of the 16S rDNA (Moeseneder et al. 
1999). 27F-FAM was 5'-end-labelled with phosphoramidite fluorochrome 5-carboxyfluorescein (5'6-FAM, Applied Biosystems). The PCR program consisted of an initial denaturation step of $94^{\circ} \mathrm{C}$ for $3 \mathrm{~min}$, followed by 30 cycles of denaturation at $94^{\circ} \mathrm{C}$ for $1 \mathrm{~min}$, annealing at $55^{\circ} \mathrm{C}$ for $1 \mathrm{~min}$ and extension at $72^{\circ} \mathrm{C}$ for $1 \mathrm{~min}$. During the last cycle, the extension step was increased to 7 min. For amplification of $18 \mathrm{~S}$ rDNA for T-RFLP, the same primer pair and PCR program as for DGGE was used, except that primer Euk1F was 5'-labelled with FAM and primer Euk516RGC did not have the GC clamp. Fluorescently labelled PCR products were purified using a PCR purification kit (Qiagen).

T-RFLP analysis. Purified FAM-labelled PCR products were digested with restriction enzymes at $37^{\circ} \mathrm{C}$ for $4 \mathrm{~h}$. Each digest contained $4 \mu \mathrm{l}$ PCR product, $5 \mathrm{U}$ of the restriction enzymes Msp I (eukaryotic PCR products) or Cfo I (bacterial PCR products) and the recommended buffer. Terminal restriction fragments (TRFs) were separated and detected by electrophoresis at $3000 \mathrm{~V}$ for $5 \mathrm{~h}$ in a denaturing $5 \%$ acrylamide gel with an ABI Prism 377 automated sequencer. Before loading the samples, $3 \mu$ restriction digest was denatured in the presence of $2.5 \mu \mathrm{l}$ deionised formamide at $90^{\circ} \mathrm{C}$ for 2 min. The sizes of TRFs, which represent different operational taxonomic units (OTUs), were determined by comparison with the internal size standard ROX 500 or ROX 1000 (Applied Biosystems) by using the local southern size-calling method of the GeneScan 3.1 software (Applied Biosystems). The detection threshold was set to 25 RFU (relative fluorescent units) for the GeneScan software. Additionally, all peaks were checked manually for correct size and shape. The relative abundance of each TRF within 1 sample was determined by calculating the ratio between the peak height of each TRF and the total peak height of all TRFs within this sample (Osborn et al. 2000).

DGGE analysis. DGGE was performed as described by Muyzer \& Smalla (1998) using a Dcode Universal Mutation Detection System (Bio-Rad). Electrophoresis was performed with $1 \mathrm{~mm}$ thick $6 \%$ polyacrylamide gels (ratio of acrylamide to bisacrylamide, 37.5:1) submerged in $1 \mathrm{X}$ TAE buffer (40 mM Tris, $40 \mathrm{mM}$ acetic acid, $1 \mathrm{M}$ EDTA; $\mathrm{pH} \mathrm{7.4)}$ at $60^{\circ} \mathrm{C}$. Around $30 \mu \mathrm{l}$ of PCR product were loaded in each lane. Electrophoresis conditions were $100 \mathrm{~V}$ for $16 \mathrm{~h}$ in a linear denaturing gradient of 40 to $80 \%$ (16S rDNA amplicons) or 40 to $65 \%$ (18S rDNA amplicons) (100\% denaturant agent was defined as $7 \mathrm{M}$ urea and $40 \%$ deionised formamide). The gels were stained for $30 \mathrm{~min}$ in $1 \mathrm{X}$ TAE buffer with SybrGold nucleic acid stain (Molecular Probes), visualised by UV radiation and pictures were taken by a digital gel documentation system (Syngene, Gene Snap).

Digitised images of DGGE gels were processed with the Diversity Database software (Bio-Rad). The soft- ware carries out a density profile through each lane, detects the bands and then calculates the relative contribution of each band to the total band signal in the lane after applying a rolling disk as background subtraction. Bands occupying the same position in different lanes were identified. A band was defined as a positive signal whose intensity was more than $1 \%$ of the total intensity of the respective lane. The number of operational taxonomic units (OTUs) in each sample was defined as the number of DGGE bands.

\section{RESULTS}

\section{Dynamics of bacterial and protist abundance}

Bacteria started to grow in the chemostats with a $1 \mathrm{~d}$ lag phase after inoculation (Fig. 1), and within $4 \mathrm{~d}$ they reached maximal concentrations of 7.2 to $7.7 \times 10^{6}$ cells $\mathrm{ml}^{-1}$. The general phenotypic picture of the bacterial assemblage, as seen in the epifluorescence microscope, was similar in all 4 chemostat vessels, with single freely suspended bacteria, mainly rod-shaped cells with cell lengths between 0.7 and $2.3 \mu \mathrm{m}$ and a mean volume in the range of 0.15 to $0.20 \mathrm{\mu m}^{3}$. In the remaining flagellate-free experimental period of B1 and B2, bacterial concentrations fluctuated irregularly between 4 and $7 \times 10^{6}$ cells ml $^{-1}$, with mean values of 5.70 and $5.95 \times 10^{6}$ cells ml ${ }^{-1}$ in B1 and B2, respectively.

After $12 \mathrm{~d}$ of cultivation, HNF were introduced with the $<2 \mu \mathrm{m}$ inoculum in the chemostat vessels F1 and F2. An exponential increase of HNF started 3 to $4 \mathrm{~d}$ after this inoculation and resulted in maximal HNF concentrations of 25 to $28 \times 10^{3}$ cells $\mathrm{ml}^{-1}$. This was paralleled by a strong decline in bacterial numbers to $0.2-0.3 \times 10^{6}$ cells $\mathrm{ml}^{-1}$. After the initial peak, HNF numbers declined but remained at different, fluctuating levels between the 2 replicate chemostats until the end of the experiment: 3 to 8 and 5 to $20 \times 10^{3}$ cells ml $^{-1}$ in F1 and F2, respectively. Microscopical observations of live samples and of fixed, DAPI-stained preparations, revealed that the HNF assemblage was heterogeneous and included cells of different size, shape and swimming behaviour. The majority of HNF (>90\%) were 3 to $6 \mu \mathrm{m}$ in cell size. No chlorophyll-containing cells nor protists other than HNF (e.g. ciliates, amoebae) were detected in any of the samples.

The 2 bacterial chemostats B1 and B2 were maintained for more than 1 mo without flagellate predators. At Day 32, a contamination by HNF (only 1 type, a Spumella-like nanoflagellate) was detected in B1 and B2. The rapid increase in HNF numbers then caused the collapse of the bacterial assemblage to $<0.5 \times 10^{6}$ cells $\mathrm{ml}^{-1}$ at the end of the experiment (Fig. 1). Bacterial concentrations remained at low levels (mostly 0.3 to 


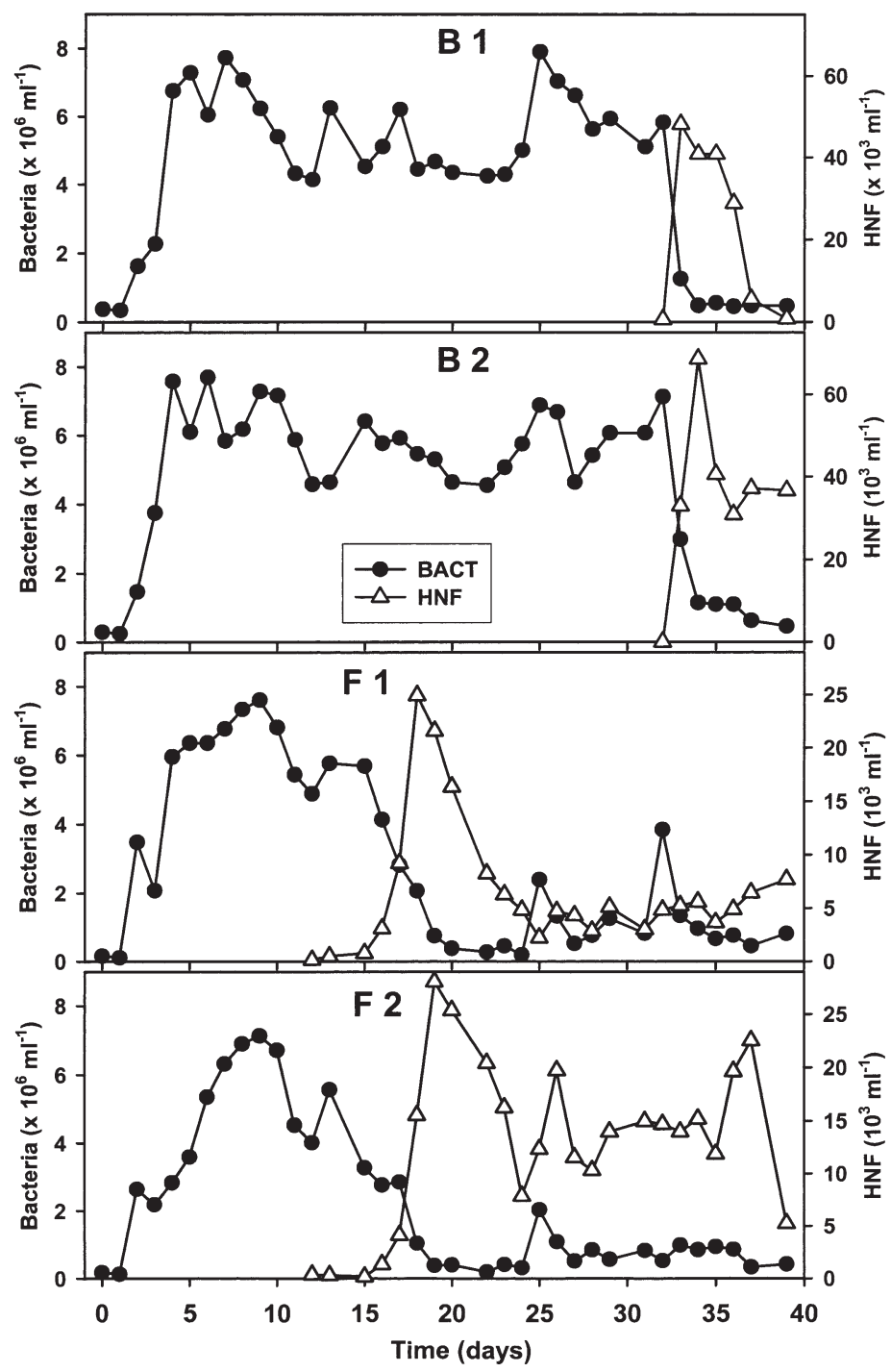

Fig. 1. Population dynamics of bacteria $(\bullet)$ and heterotrophic nanoflagellates (HNF) $(\Delta)$ in the control chemostats B1 and B2 and the flagellate chemostats F1 and F2

$0.9 \times 10^{6} \mathrm{ml}^{-1}$ ) in the flagellate chemostats, except for 2 brief bacterial peaks in F1 and 1 peak in F2, during which bacteria increased for 1 sampling date above $2 \times 10^{6} \mathrm{ml}^{-1}$ (Fig. 1). These short-lasting increases in the bacterial assemblage consisted of normal, small rod-shaped bacterial cells without any new, peculiar bacterial morphologies.

A more detailed morphological analysis of the remaining ungrazed bacteria in F1 and F2 was performed for the last 4 sampling dates of the experiment. As an estimate for the proportion of inedible bacteria we defined bacteria with a cell length $>5 \mu \mathrm{m}$ and cell clusters of more than 10 cells as resistant to predation because they exceeded the diameter of most of the flagellates. It revealed that only around $20 \%$ of the bacterial biovolume consisted of morphologically grazing-protected cells such as elongated rods or filaments and bacteria embedded in small aggregates (Table 1). In terms of bacterial concentrations these numbers were obviously lower: only $14 \%$ (F1) and 9\% (F2) of total bacteria. A similar type of morphological analysis to the bacterial assemblages in B1 and B2 revealed that these contained on average $5.5 \%$ (B1) and $10.6 \%$ (B2) of bacterial biovolume in the form of resistant bacterial morphotypes. The absolute values of bacterial biovolume in the form of aggregates or filaments were even higher in B than in F treatments (Table 1).

\section{Bacterial composition as determined by FISH}

To get an idea of the contribution of the major phylogenetic groups to the bacterial assemblages, we performed, on 4 successive sampling dates (Days 26 to 29), a FISH analysis with general group-specific probes and 3 probes for clusters inside the $\gamma$-Proteobacteria. There was no major visible difference in the overall bacterial composition between the B and the F treatments. The detectability of bacteria with the EUB probe was between 67 and $78 \%$ of total DAPI counts. Bacteria which gave no positive signal with the EUB probe were mainly very small coccoid cells. Most of the EUB positive cells could be affiliated with one of the group-specific probes (Table 2). All inspected samples were strongly dominated by $\gamma$-Proteobacteria: between 50 and $70 \%$ of total bacteria hybridised with the GAM42a probe, whereas the other 3 bacterial groups ( $\alpha$-Proteobacteria, $\beta$ Proteobacteria and Cytophaga/Flavobacterium) accounted only for 1 to $10 \%$ of total DAPI counts (Table 2). A significant fraction of bacteria hybridised with the specific probe for the Alteromonas cluster within the $\gamma$-Proteobacteria (24 to $34 \%$ ), whereas a smaller fraction hybridised with the probe for Pseudoalteromonas (3 to $9 \%$ ) and no bacteria were detected with the probe for the SAR 86 cluster (Table 2). This means that on average between 44 and $73 \%$ of the $\gamma$-Proteobacteria consisted of the genera Alteromonas and Pseudoalteromonas.

\section{Dynamics of bacterial and protist composition}

$$
\text { T-RFLP }
$$

The bacterial assemblage which had developed after $2 \mathrm{~d}$ in continuous cultivation was already very different from that in the inoculum (Fig. 2). Six out of 22 OTUs of the inoculum did not appear in the chemostat samples. The communities in all 4 chemostats became dominated by 6 TRFs, which persisted throughout the experimental period but in varying relative intensities 
Table 1. Morphological analysis of the chemostat bacterial assemblages performed on 4 consecutive sampling dates (Days 26 to 29 for B, Days 34 to 37 for F). Mean biovolume values $( \pm \mathrm{SD}$ ) of the whole bacterial assemblages and bacterial biovolume partitioned in 3 different morphotype classes (in $10^{5}$ $\mu \mathrm{m}^{3} \mathrm{ml}^{-1}$ ) are given. Bacterial filaments and bacteria in aggregates were considered to be inedible morphologies for bacterial grazers

\begin{tabular}{|c|c|c|c|c|}
\hline & B1 & B2 & F1 & F2 \\
\hline \multicolumn{5}{|c|}{ Bacterial biovolume $\left(10^{5} \mu^{3} \mathrm{ml}^{-1}\right)$} \\
\hline Total & $9.54(1.31)$ & $10.91(1.36)$ & $1.19(0.27)$ & $1.16(0.39)$ \\
\hline Freely suspended & $9.02(1.30)$ & $9.78(1.44)$ & $0.91(0.23)$ & $0.95(0.36)$ \\
\hline Aggregates & $0.35(0.08)$ & $0.34(0.21)$ & $0.15(0.03)$ & $0.06(0.01)$ \\
\hline Filaments & $0.17(0.09)$ & $0.80(0.35)$ & $0.13(0.04)$ & $0.21(0.02)$ \\
\hline $\begin{array}{c}\text { Inedible bacterial } \\
\text { biovolume }(\%)\end{array}$ & $5.5(1.0)$ & $10.6(2.2)$ & $23.9(3.7)$ & $19.9(4.2)$ \\
\hline
\end{tabular}

Table 2. Relative abundance of major phylogenetic bacterial groups in the chemostats as determined by fluorescent in situ hybridisation (FISH). All values are percentages of DAPI-stained bacteria detectable with the corresponding probes. Mean $( \pm \mathrm{SD})$ of 4 successive sampling dates (Days 26 to 29)

\begin{tabular}{|lrccc|}
\hline & B1 & B2 & F1 & F2 \\
\hline EUB338 & $71.7(9.5)$ & $67.7(3.6)$ & $78.4(9.5)$ & $78.0(7.3)$ \\
ALF968 & $3.1(2.1)$ & $4.2(1.0)$ & $7.0(3.8)$ & $3.1(1.3)$ \\
CF319a & $5.0(3.3)$ & $7.4(5.8)$ & $9.8(4.6)$ & $5.5(6.6)$ \\
BET42a & $4.4(1.3)$ & $1.2(0.7)$ & $2.5(2.2)$ & $5.7(5.2)$ \\
GAM42a & $60.5(1.2)$ & $50.9(17.5)$ & $70.7(13.0)$ & $50.4(13.1)$ \\
ALT1413 & $24.1(6.7)$ & $34.3(4.5)$ & $32.3(1.2)$ & $25.9(10.0)$ \\
PSA184 & $2.6(1.6)$ & $2.8(0.6)$ & $9.3(4.3)$ & $8.9(3.2)$ \\
\hline
\end{tabular}

Table 3. Summary results of DGGE and terminal-restriction fragment length polymorphism (T-RFLP) analyses of bacterial and eukaryal community compositions in the chemostats (OTU = operational taxonomic unit)

\begin{tabular}{|c|c|c|c|c|c|c|c|c|}
\hline & \multicolumn{5}{|c|}{ - Bacteria } & \multicolumn{3}{|c|}{ — Eukarya - } \\
\hline & $\begin{array}{l}\text { Inoc- } \\
\text { ulum }\end{array}$ & B1 & B2 & F1 & F2 & $\begin{array}{l}\text { Inoc- } \\
\text { ulum }\end{array}$ & F1 & $\mathrm{F} 2$ \\
\hline \multicolumn{9}{|c|}{ Total number of OTUs } \\
\hline T-RFLP & 22 & 28 & 29 & 30 & 26 & 14 & 14 & 15 \\
\hline DGGE & 13 & 17 & 14 & 16 & 19 & 7 & 10 & 12 \\
\hline \multicolumn{9}{|c|}{ Average number of OTUs per sample } \\
\hline T-RFLP & - & 10.8 & 10.3 & 8.6 & 10.2 & - & 3.4 & 5.8 \\
\hline DGGE & - & 9.0 & 7.9 & 6.5 & 9.0 & - & 5.7 & 5.6 \\
\hline \multicolumn{9}{|c|}{ Intensity (\%) dominant OTUs ${ }^{\mathrm{a}}$} \\
\hline T-RFLP & 17.4 & 73.3 & 80.2 & 89.2 & 84.0 & 56.7 & 88.8 & 81.2 \\
\hline DGGE & 19.6 & 79.3 & 88.7 & 86.5 & 75.3 & 57.7 & 98.8 & 92.9 \\
\hline
\end{tabular}

(Fig. 2). These dominant TRFs represented around $80 \%$ of total TRF intensity in the chemostats, but less than $20 \%$ in the inoculum (Table 3), providing further evidence for the change in bacterial composition between the inoculum and the chemostat cultures.
The inoculation of natural protists in F1 and F2 (arrows in Fig. 2) did not seem to result in significant changes in the dynamics and proportions of the TRFs as compared to B1 and B2. In the 4 chemostats, both the total number of OTUs (between 26 and 30) and the average number of OTUs in each sampling (between 9 and 11) was similar (Table 3 ). In addition, the 4 chemostats were dominated by the same 6 TRFs, which comprised 73 to $89 \%$ of the total fluorescence signal (Table 3). The decline of the TRF 206 in the F treatments also occurred in the protist-free treatments, although some days later.

In contrast to the relatively stable bacterial composition during the experimental period, eukaryotic OTUs in F1 and F2 exhibited a very dynamic succession (Fig. 3). The 8 dominant TRFs, whose intensity comprised on average 89 and $81 \%$ in F1 and $F 2$, respectively, did not occur simultaneously, but in a temporal sequence where 2 to 4 dominant OTUs appeared together. Strong changes with a replacement of dominant OTUs occurred particularly after Day 22. The total number of eukaryotic fragments in chemostat samples, 14 to 15 , was similar to that in the inoculum (Table 3 ), but 7 of the OTUs in the inoculum did not show up during the chemostat run. The succession of OTUs deviated strongly between the 2 parallel treatments, and at most sampling times, F1 and F2 were dominated by different OTUs (Fig. 3).

\section{DGGE}

Examples of DGGE profiles analysing the temporal changes of the bacterial assemblages are shown in Fig. 4A. Interestingly, they reflect the same patterns as revealed already from the T-RFLP analysis. The shift in the bacterial assemblage after $3 \mathrm{~d}$ of continuous cultivation was evident, with only 6 out of 13 bands from the inoculum still present in the chemostat assemblage. Fewer OTUs were detected by DGGE than by T-RFLP, and the bacterial communities, which became established in the different chemostats, consisted of a total of 14 to 19 bands. The relative intensity accounted for the 6 dominant bands was between 79 and $89 \%$, a figure remarkably similar to that found by $\mathrm{T}$ RFLP (Table 3). The average number of OTUs per 

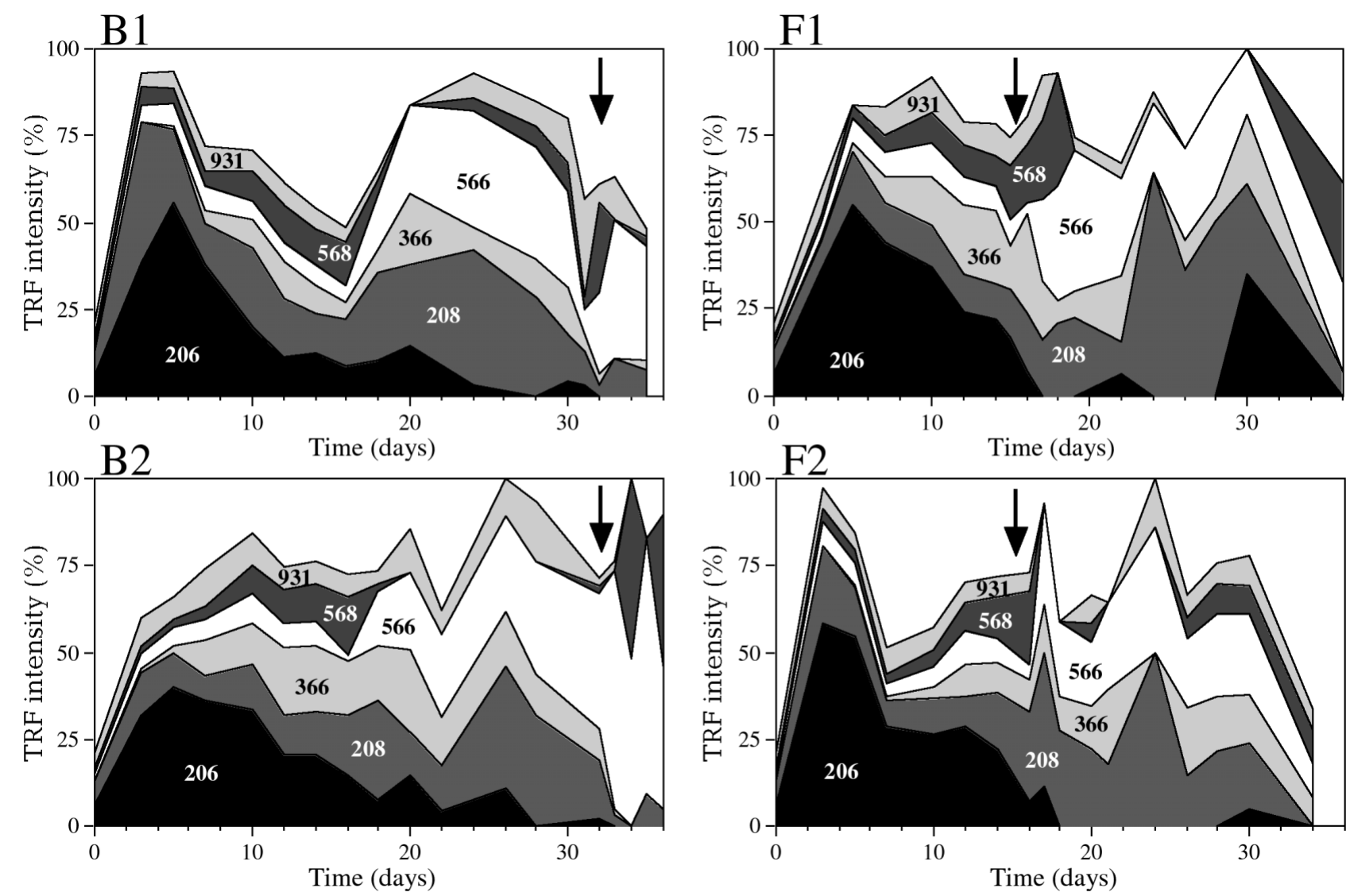

Fig. 2. Dynamics of bacterial composition in chemostats B1, B2, F1 and F2 as revealed from terminal-restriction fragment length polymorphism (T-RFLP) fingerprints. Development of the relative intensities of the 6 dominant terminal restriction fragments (TRFs) (numbers refer to the length of the respective fragment) during the experimental period is shown. White area at the top represents the relative intensity of the remaining TRFs. Arrows indicate time of flagellate inoculation (F1, F2) or contamination with flagellates (B1, B2), respectively

sample was 7 to 9 , also comparable to that found by TRFLP. As was the case with the T-RFLP patterns, the DGGE profiles revealed that only modest changes (mainly with respect to the relative intensities of the different bands) occurred within the bacterial assemblage during the course of the experiment, and that the bacterial compositions between the $\mathrm{B}$ and the $\mathrm{F}$ chemostats were rather similar (Fig. 4A).

The DGGE profiles of the eukaryotic assemblages, for which the pattern of F2 is shown in Fig. 4B, showed, similar to T-RFLP, obvious changes especially after Day 22. The total number of bands increased to 10 to 12 compared to 7 in the inoculum, from which 4 did not appear again during the chemostat run. The eukaryotic assemblages were dominated at each sampling point by 5 to 6 bands which comprised 93 to $99 \%$ of total signal intensity (Table 3 ). The flagellate contaminations which occurred at the end of the experiment in B1 and B2 were reflected by 1 single, strong band in the DGGE (Fig. 4B) which was also present at this position in the flagellate chemostats.

\section{DISCUSSION}

Our goal was to study bacteria-protist interactions in a marine plankton model community which resembles in its main features the natural situation. To achieve this, we chose a continuous culture system with unsupplemented natural seawater as growth medium. The naturally present dissolved organic matter (DOM), a mixed bacterial inoculum from the same water and a relatively low dilution rate (corresponding to a bacterial doubling time of about $1.5 \mathrm{~d}$ ) should have created close to in situ conditions for the bacterial assemblages. We also assumed that the natural substrate mixture in filtered seawater should allow the development and coexistence of a diverse bacterial community in the chemostats. The analysis by T-RFLP indeed revealed that up to 30 different sequence types (on average around 10 per sampling point) were present in the reactors. This is within the range of OTU numbers generally detected in marine planktonic samples by DGGE (e.g. Schauer et al. 2000, Schäfer et al. 2001) or 

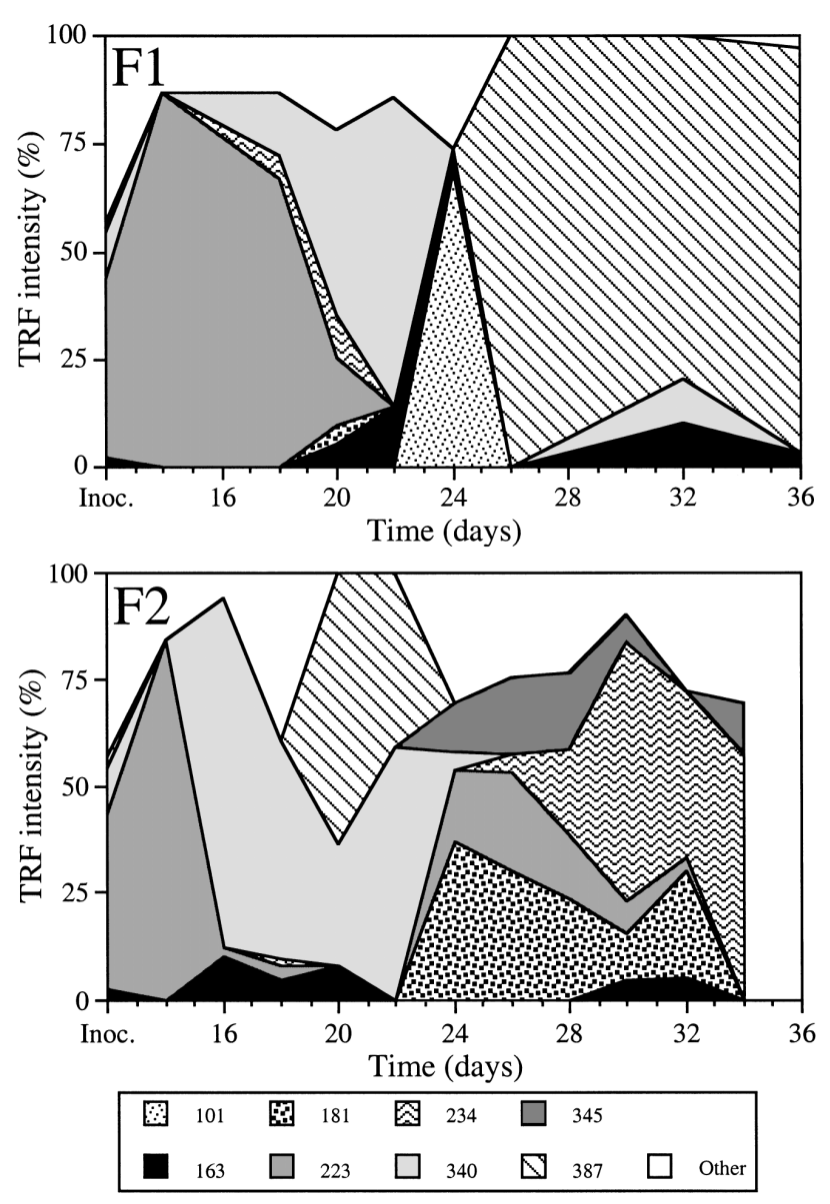

Fig. 3. Dynamics of protist composition as revealed from terminal-restriction fragment length polymorphism (T-RFLP) fingerprints. Development of the relative intensities of the 8 dominant terminal restriction fragments (TRFs) (numbers in legend refer to the length of the respective fragment) and of the pooled other fragments (white area at top) during the experimental period is shown

T-RFLP (Moeseneder et al. 2001). Due to the fact that strains which are present in very low numbers are generally not detected by these fingerprinting techniques (Liu et al. 1997, Muyzer 1999), the actual total number of bacterial taxa could have been even higher. A high number of bacterial species should also potentially involve the presence of different bacterial defence strategies and enable a feed-back response, such as the development of predation-resistant populations. Therefore, we think that the experimental system was suitable for the aim of our study, i.e. to examine the impact of enhanced and continuous protist grazing on a mixed marine bacterial community, and to follow changes in morphological and taxonomical composition.

Genetic fingerprinting techniques, based on the amplification of $16 \mathrm{~S}$ and $18 \mathrm{~S}$ rRNA genes, are now widely used to compare microbial community struc- tures and to follow changes in microbial community composition (Muyzer 1999, Osborn et al. 2000). Both DGGE and T-RFLP are routinely used to assess bacterial community structure and have also been used for microbial eukaryotes (Marsh et al. 1998, Van Hannen et al. 1999, Díez et al. 2001a). We used the presence of different OTUs (fragment sizes in T-RFLP, band position in DGGE) as well as the relative intensities of TRFs and DGGE bands to describe the microbial communities in the chemostats. We are aware that this quantitative information might be compromised because of the potential biases involved in PCR-based approaches (Suzuki \& Giovannoni 1996, Von Witzingerode et al. 1997). There is, however, evidence from other studies that band intensities of DGGE fingerprints can be used to follow relative changes of populations, but cannot be used for the assessment of absolute abundances (Nübel et al. 1999, Casamayor et al. 2000, Schauer et al. 2000). The simultaneous application of DGGE and T-RFLP, which are independent and rely on different primer sets, gives a more reliable assessment of the bacterial and protist community dynamics.

T-RFLP proved to be more sensitive and yielded more OTUs than DGGE, which is in accordance with previous studies comparing the 2 techniques (Marsh et al. 1998, Moeseneder et al. 1999). Both approaches gave, however, basically the same picture of the microbial structure and succession in our experiment. This was characterised by the following features: (1) bacterial composition changed significantly during continuous cultivation compared to the initial inoculum; (2) the bacterial community composition remained relatively constant, independent of the presence of grazers, and the same major populations were present in all reactors during most of the experimental time; and (3) a pronounced succession occurred within the protist community of the reactors F1 and F2 with at least 8 taxa appearing at higher abundance at different points of the experiment.

The enrichment of $\gamma$-Proteobacteria in our systems is similar to that reported for conventional bacterial isolation techniques with artificial liquid or solid media (Wagner et al. 1993, Eilers et al. 2000a). A shift to $\gamma$-Proteobacteria and to the genus Alteromonas, which was also a main taxon in our chemostats, was also found in a Mediterranean mesocosm experiment (Schäfer et al. 2000) and thus, it might be a general phenomenon of confined bacterioplankton communities. Therefore, the typical composition of North Sea bacterioplankton, as determined by FISH in the study by Eilers et al. (2000b), with a dominance of $\alpha$-Proteobacteria and members of the Cytophaga-Flavobacterium cluster, and only 6 to $9 \%$ of $\gamma$-Proteobacteria, could not be maintained in the chemostats. Some fundamental aspects in which our continuous cultures differed from 

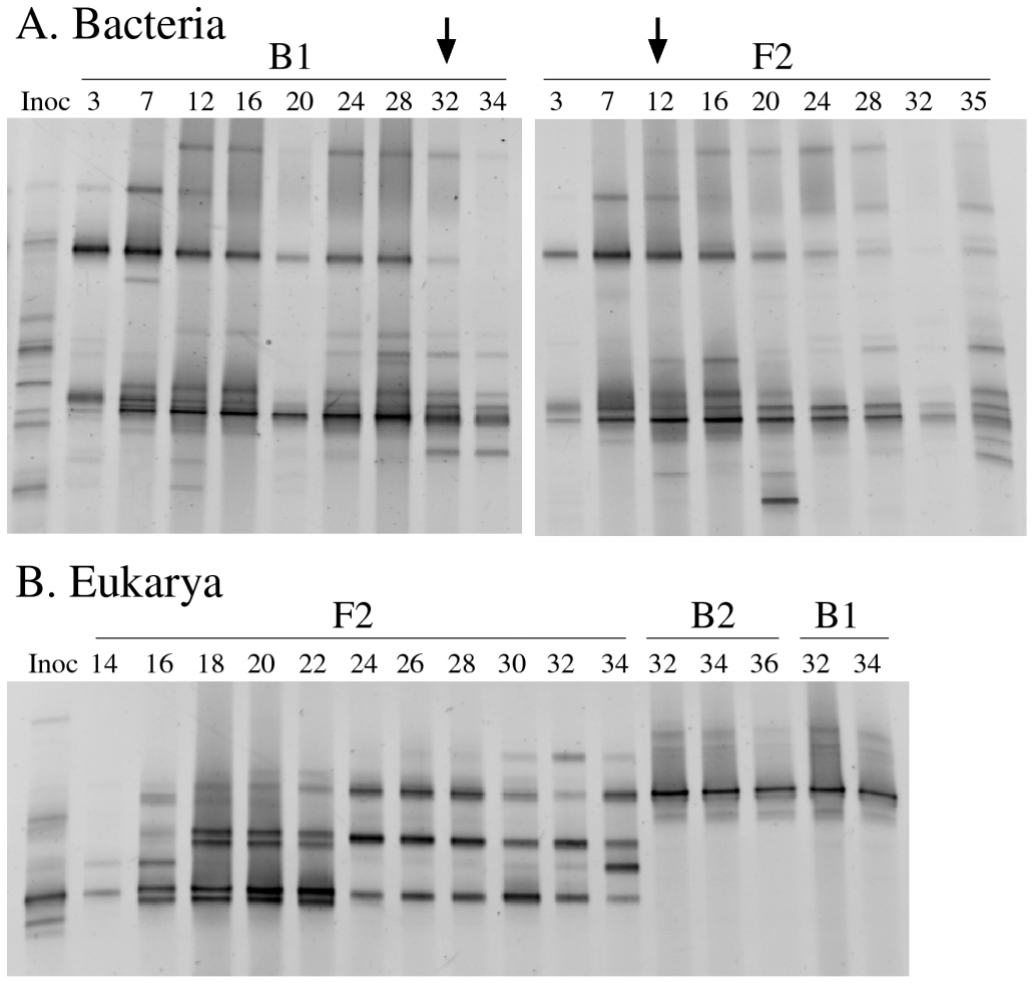

Fig. 4. Negative images of banding patterns on DGGE gels. (A) PCR-amplified bacterial 16S rDNA fragments, (B) PCR-amplified eukaryotic 18S rDNA fragments. Banding patterns of (A) the bacterial communities in B1 and F2 at different sampling days of the chemostat experiment, and (B) the protist community in F2 at different sampling days after inoculation with flagellates, and after contamination of the control chemostats B1 and B2 at the end of the experiment are shown. Arrows indicate time of flagellate inoculation (F2) or contamination (B1). Lane 'Inoc' in B1 shows the banding pattern of the initial bacterial inoculum
This model has been supported by field observations and mesocosm experiments in lakes (Güde 1989, Langenheder \& Jürgens 2001) and by chemostat experiments with freshwater microbial assemblages (Hahn \& Höfle 1999, Posch et al. 1999).

In these experiments, a surprisingly high capacity of bacterial communities seem to exist that can develop grazing resistance at the upper end of the cell size distribution (e.g. filamentous forms, aggregates), in response to enhanced protist predation. Resistant bacterial morphotypes appeared in different phylogenetic groups, such as the $\alpha$ - and $\beta$-Proteobacteria and the Cytophaga-Flavobacterium cluster (Jürgens et al. 1999, Šimek et al. 1999, 2001, Langenheder \& Jürgens 2001). The development of grazing-resistance can be due either to phenotypic plasticity of certain strains, to a shift towards inedible species or a combination of both (reviewed by Jürgens \& Matz 2002). In chemostat studies, the compensation of grazing mortality by the development of resistant bacteria can result in nearly similar bacterial biomass levels between control and grazer treatments (Pernthaler et al. 1997, Šimek et al. 1997, Matz \& Jürgens 2003).

natural systems is the absence of particles, the continuous substrate (DOM) supply and the washout of dormant or slow-growing (less than the dilution rate) bacterial cells. Changes in substrate composition might include enrichment effects due to the filtration procedure, but also depletion due to the removal of autotrophs and detritus aggregates. Although seawater chemostat cultures are one of the cultivation techniques that better resemble the natural situation, they can obviously represent only a fraction of the (actively growing) in situ bacterial assemblage.

During recent years, some insight into the underlying mechanisms of the interactions between planktonic bacteria and bacterivorous protists has been achieved by experimental field and laboratory studies. The majority of these studies are from limnic systems. The conceptual model on the impact of predation on the morphological structure of bacterioplankton, as depicted by Güde (1989), implies that flagellate grazing eliminates mainly medium-sized cells and shifts bacterial size structure towards smaller and larger bacteria, which both suffer lower grazing mortality.
In our system, the dilution rate, an important structuring factor for populations in continuous cultures, was in a range comparable to the above-mentioned chemostat studies. However, in contrast to these studies the feedback response of the bacterial assemblage was very low in our experiment, despite strong and prolonged protist grazing pressure. Instead, the bacterial assemblage seemed to remain efficiently top-down controlled by the protist community for the whole experimental period. Bacterial biomass was reduced to about $10 \%$ of the level present in the grazer-free chemostats (B1, B2). Applying morphological criteria, only about $20 \%$ of the ungrazed bacteria consisted of resistant morphotypes, such as elongated cells and bacteria embedded in aggregates. Small bacterial cells below the critical size to be efficiently ingested by nanoflagellates did not develop in higher numbers. The fact that, in absolute numbers, even more morphologically resistant bacteria were present in the B chemostats (Table 1) indicated that these cells occurred independent of grazers, but increased in relative abundance in F1 and F2 when protists grazing selectively eliminated the unprotected bacteria. Besides 
morphological inedibility, other resistance mechanisms might also have occurred (Jürgens \& Matz 2002); however, the low bacterial biomass in the grazer chemostats is the strongest evidence for efficient top-down control.

Strong grazing pressure by bacterivores results not only in morphological changes of bacterial communities but generally also in taxonomic shifts (Pernthaler et al. 1997, Šimek et al. 1997, 2001, Jürgens et al. 1999. This was not (or only weakly) the case in our experiments as seen from the community analysis by DGGE and T-RFLP. Both fingerprinting techniques revealed that the bacterial communities in the chemostats neither differed considerably between the different reactors (Figs. 2 \& 4), nor that drastic changes occurred during the course of the experiment. Although the relative proportions of the different OTUs changed, the same dominant OTUs were still present at the end of the experiment (Fig. 2).

We can think of 2 possible major explanations for the low ability of the bacterial communities in our chemostats to develop grazing resistance. First, marine bacterioplankton assemblages might contain fewer bacterial species which possess adaptations to resist protist predation. Whereas size-selective grazing and the resulting shift towards small cells has also been demonstrated for marine bacterioplankton (González et al. 1990, Jürgens et al. 2000), much less evidence exists for the appearance of grazing-resistant large or complex morphologies in marine waters. However, the development of filamentous bacteria in response to protist grazing has been reported for some micro- and mesocosm experiments with coastal seawater (Caron et al. 1988) and with brackish water from the Baltic Sea (Havskum \& Hansen 1997, Engström-Öst et al. 2002). It might not only be a question of salinity, but also of productivity (substrate supply) of the system that determines whether resistant bacteria can develop. Considering the bacterial concentrations and doubling times in our chemostat systems, the productivity level is certainly comparable to mesotrophic freshwater lakes in which grazing-resistant bacteria seem to be a frequently occurring phenomenon (Jürgens \& Matz 2002).

The second explanation for the lack of significant bacterial resistance in our experiment could be that, in contrast to the previous chemostat studies, we used a natural inoculum containing different flagellate species instead of only a single bacterial predator. The picture for the dynamics of the protistan assemblage looked quite different from that for the bacteria: here both flagellate treatments F1 and F2 deviated from each other in terms of cell numbers (Fig. 1) and composition (Fig. 2). Total species richness of the protist community, which according to microscopical inspec- tion of live samples consisted exclusively of HNFs, was high (around 15 OTUs according to T-RFLP; see Table 3) and a pronounced succession occurred during the course of the experiment (Figs. 2 \& 4). Recent studies suggest that there is a high functional diversity within communities of co-occurring heterotrophic flagellates (Arndt et al. 2000, Boenigk \& Arndt 2002). Although we do not have information on the species composition nor on the feeding characteristics of the flagellate assemblages in our experiment, it is likely that they comprised cells with different feeding types and food preferences. Bacterial adaptations towards grazers might to some extent be predator-specific. Evidence for this comes from chemostat studies by Posch et al. (1999) and Pernthaler et al. (2001b) with freshwater bacterial assemblages and different bacterivorous protists. The responses in the bacterial communities, e.g. development of very small or elongated cells, were specific towards different bacterivores. Therefore, it seems probable that the existence of a complex grazer community, which generally resembles the natural situation, with differing food uptake mechanisms and foraging behaviour, can exert a much wider grazing pressure than a single bacterivorous species. There are presumably no bacterial resistance mechanisms which are effective, at moderate costs, against all types of grazers. The observed eukaryotic succession with a replacement of protist species might have prevented the significant development of a certain type of resistant bacteria.

It is evident from this study with a natural mixed assemblage of bacterial predators as well as from those which compared different protist species (Posch et al. 1999, Pernthaler et al. 2001b) that the taxonomic composition of the protist community can play an important role for the structuring of bacterial communities. More information about the diversity of protist communities has been accumulating recently (e.g. Díez et al. 2001b, Moon-van der Staay et al. 2001) and molecular methods are being developed for a quantitative analysis of the smallest heterotrophic eukaryotes (Massana et al. 2002). Due to the lack of comparable studies with marine assemblages, it is too early to draw any general conclusions about differences in predator-prey interactions between freshwater and marine systems. To obtain further insights into the capability of marine bacterial assemblages to adapt towards different predators, studies with complex natural communities should be combined with experiments with defined populations of bacteria and protists, similar to those carried out with freshwater assemblages.

Acknowledgements. This study was supported by the German Science Foundation (DFG grant no. JU 367/4-2 to K.J.), by the EU project PICODIV (EVK3-CT1999-00021) and by a 
CSIC-MPG travel grant to R.M. We are grateful to Ines Schulz, Heike Wardenga and Sybille Liedke for their technical assistance in the laboratory. We also thank Dr. K. Wiltshire and the Biological Station of Helgoland for help in obtaining North Sea water and for providing nutrient data.

\section{LITERATURE CITED}

Amann RI, Ludwig W, Schleifer KH (1995) Phylogenetic identification and in situ detection of individual microbial cells without cultivation. Microbiol Rev 59:143-169

Arndt H, Dietrich D, Auer B, Cleven EJ, Gräfenhan T, Weitere M, Mylnikov A (2000) Functional diversity of heterotrophic flagellates in aquatic ecosystems. In: Leadbeater B, Green J (eds) The flagellates. Taylor \& Francis, London, p 240-268

Boenigk J, Arndt H (2002) Bacterivory by heterotrophic flagellates: community structure and feeding strategies. Antonie Leeuwenhoek 81:465-480

Caron DA, Goldman JC, Dennett MR (1988) Experimental demonstration of the roles of bacteria and bacterivorous protozoa in plankton nutrient cycles. Hydrobiologia 159: $27-40$

Casamayor EO, Schäfer H, Baneras L, Pedrós-Alió C, Muyzer $\mathrm{G}$ (2000) Identification of and spatio-temporal differences between microbial assemblages from two neighboring sulfurous lakes: comparison by microscopy and denaturing gradient gel electrophoresis. Appl Environ Microbiol 66:499-508

Díez B, Pedrós-Alió C, Marsh TL, Massana R (2001a) Application of denaturing gradient gel electrophoresis (DGGE) to study the diversity of marine picoeukaryotic assemblages and comparison of DGGE with other molecular techniques. Appl Environ Microbiol 67:2942-2951

Díez B, Pedrós-Alió C, Massana R (2001b) Study of genetic diversity of eukaryotic picoplankton in different oceanic regions by small-subunit rRNA gene cloning and sequencing. Appl Environ Microbiol 67:2932-2941

Eilers H, Pernthaler J, Amann R (2000a) Succession of pelagic marine bacteria during enrichment: a close look at cultivation-induced shifts. Appl Environ Microbiol 66:4634-4640

Eilers H, Pernthaler J, Glöckner FO, Amann R (2000b) Culturability and in situ abundance of pelagic bacteria from the North Sea. Appl Environ Microbiol 66:3044-3051

Engström-Öst J, Koski M, Schmidt K, Viitasalo M, Jonasdottir SH, Kokkonen M, Repka S, Sivonen K (2002) Effects of toxic cyanobacteria on a plankton assemblage: community development during decay of Nodularia spumigena. Mar Ecol Prog Ser 232:1-14

Fenchel T (1986) The ecology of heterotrophic microflagellates. Adv Microb Ecol 9:57-97

González JM, Sherr EB, Sherr BF (1990) Size-selective grazing on bacteria by natural assemblages of estuarine flagellates and ciliates. Appl Environ Microbiol 56:583-589

González JM, Sherr EB, Sherr BF (1993) Differential feeding by marine flagellates on growing versus starving, and on motile versus nonmotile, bacterial prey. Mar Ecol Prog Ser 102:257-267

Güde H (1989) The role of grazing on bacteria in plankton succession. In: Sommer U (ed) Plankton ecology: succession in plankton communities. Springer-Verlag, Berlin, p 337-364

Hahn MW, Höfle MG (1999) Flagellate predation on a bacterial model community: interplay of size-selective grazing, specific bacterial cell size, and bacterial community composition. Appl Environ Microbiol 65:4863-4872
Hahn MW, Höfle MG (2001) Grazing of protozoa and its effect on populations of aquatic bacteria. FEMS Microbiol Ecol 35:113-121

Havskum H, Hansen AS (1997) Importance of pigmented and colourless nano-sized protists as grazers on nanoplankton in a phosphate-depleted Norwegian fjord and in enclosures. Aquat Microb Ecol 12:139-151

Jürgens K, Güde H (1994) The potential importance of grazing-resistant bacteria in planktonic systems. Mar Ecol Prog Ser 112:169-188

Jürgens K, Matz C (2002) Predation as a shaping force for the phenotypic and genotypic composition of planktonic bacteria. Antonie Leeuwenhoek 81:413-434

Jürgens K, Stolpe G (1995) Seasonal dynamics of crustacean zooplankton, heterotrophic nanoflagellates and bacteria in a shallow, eutrophic lake. Freshw Biol 33:27-38

Jürgens K, Pernthaler J, Schalla S, Amann R (1999) Morphological and compositional changes in a planktonic bacterial community in response to enhanced protozoan grazing. Appl Environ Microbiol 65:1241-1250

Jürgens K, Gasol JM, Vaqué D (2000) Bacteria-flagellate coupling in microcosm experiments in the Central Atlantic Ocean. J Exp Mar Biol Ecol 245:127-147

Langenheder S, Jürgens K (2001) Regulation of bacterial biomass and community structure by metazoan and protozoan predation. Limnol Oceanogr 46:121-134

Liu WT, Marsh, T, Cheng, H, Forney, LJ (1997) Characterization of microbial diversity by determining terminal restriction fragment length polymorphisms of genes encoding 16S rRNA. Appl Environ Microbiol 63:4516-4522

Marsh TL, Liu WT, Forney LJ, Cheng H (1998) Beginning a molecular analysis of the eukaryal community in activated sludge. Water Sci Technol 37:455-460

Massana R, Gasol JM, Björnsen PK, Blackburn N and 5 others (1997) Measurement of bacterial size via image analysis of epifluorescence preparations-description of an inexpensive system and solutions to some of the most common problems. Sci Mar 61:397-407

Massana R, Guillou L, Díez B, Pedrós-Alió C (2002) Unveiling the organisms behind novel eukaryotic ribosomal DNA sequences from the ocean. Appl Environ Microbiol 68: $4554-4558$

Matz C, Jürgens K (2003) Interaction of nutrient limitation and protozoan grazing determines the phenotypic composition of a bacterial community. Microb Ecol (in press)

Matz C, Boenigk J, Arndt H, Jürgens K (2002) Role of bacterial phenotypic traits in selective feeding of the heterotrophic nanoflagellate Spumella sp. Aquat Microb Ecol 27: $137-148$

Moeseneder MM, Arrieta JM, Muyzer G, Winter C, Herndl GJ (1999) Optimization of terminal-restriction fragment length polymorphism analysis for complex marine bacterioplankton communities and comparison with denaturing gradient gel electrophoresis. Appl Environ Microbiol 65: $3518-3525$

Moeseneder MM, Winter C, Herndl GJ (2001) Horizontal and vertical complexity of attached and free-living bacteria of the eastern Mediterranean Sea, determined by $16 \mathrm{~S}$ rDNA and 16S rRNA fingerprints. Limnol Oceanogr 46: 95-107

Moon-van der Staay SY, De Wachter R, Vaulot D (2001) Oceanic 18S rDNA sequences from picoplankton reveal unsuspected eukaryotic diversity. Nature 409:607-610

Muyzer G (1999) DGGE/TGGE a method for identifying genes from natural ecosystems. Curr Opin Microbiol 2: 317-322

Muyzer G, Smalla K (1998) Application of denaturing gradi- 
ent gel electrophoresis (DGGE) and temperature gradient gel electrophoresis (TGGE) in microbial ecology. Antonie Leeuwenhoek 73:127-141

Nübel U, Garcia-Pichel F, Kühl M, Muyzer G (1999) Quantifying microbial diversity: morphotypes, 16S rRNA genes, and carotenoids of oxygenic phototrophs in microbial mats. Appl Environ Microbiol 65:422-430

Osborn AM, Moore ERB, Timmis KN (2000) An evaluation of terminal-restriction fragment length polymorphism ( $\mathrm{T}$ RFLP) analysis for the study of microbial community structure and dynamics. Environ Microbiol 2:39-50

Paul J, Myers B (1982) Fluorometric determination of DNA in aquatic microorganisms by use of Hoechst 33258. Appl Environ Microbiol 43:1393-1399

Pernthaler J, Posch T, Šimek K, Vrba J, Amann R, Psenner R (1997) Contrasting bacterial strategies to coexist with a flagellate predator in an experimental microbial assemblage. Appl Environ Microbiol 63:596-601

Pernthaler J, Glöckner FO, Schönhuber W, Amann R (2001a) Fluorescence in situ hybridization (FISH) with rRNA-targeted oligonucleotide probes. In: Paul JH (ed) Marine microbiology. Methods in microbiology, Vol 30. Academic Press, San Diego, p 207-226

Pernthaler J, Posch T, Šimek K, Vrba J and 5 others (2001b) Predator-specific enrichment of Actinobacteria from a cosmopolitan freshwater clade in mixed continuous culture. Appl Environ Microbiol 67:2145-2155

Posch T, Šimek K, Vrba J, Pernthaler S, Nedoma J, Sattler B, Sonntag B, Psenner R (1999) Predator-induced changes of bacterial size-structure and productivity studied on an experimental microbial community. Aquat Microb Ecol 18: 235-246

Schäfer H, Servais P, Muyzer G (2000) Successional changes in the genetic diversity of a marine bacterial assemblage during confinement. Arch Microbiol 173:138-145

Schäfer H, Bernard L, Courties C, Lebaron P and 7 others (2001) Microbial community dynamics in Mediterranean nutrient-enriched seawater mesocosms: changes in the genetic diversity of bacterial populations. FEMS Microbiol Ecol 34:243-253

Schauer M, Massana R, Pedrós-Alió C (2000) Spatial differ-

Editorial responsibility: Karel Šimek,

České Budějovice, Czech Republic ences in bacterioplankton composition along the Catalan coast (NW Mediterranean) assessed by molecular fingerprinting. FEMS Microbiol Ecol 33:51-59

Šimek K, Vrba J, Pernthaler J, Posch T, Hartman P, Nedoma J, Psenner R (1997) Morphological and compositional shifts in an experimental bacterial community influenced by protists with contrasting feeding modes. Appl Environ Microbiol 63:587-595

Šimek K, Kojecka P, Nedoma J, Hartman P, Vrba J, Dolan JR (1999) Shifts in bacterial community composition associated with different microzooplankton size fractions in a eutrophic reservoir. Limnol Oceanogr 44:1634-1644

Šimek K, Pernthaler J, Weinbauer MG, Hornak K, Dolan JR, Nedoma J, Masin M, Amann R (2001) Changes in bacterial community composition and dynamics and viral mortality rates associated with enhanced flagellate grazing in a mesoeutrophic reservoir. Appl Environ Microbiol 67: 2723-2733

Sommaruga R, Psenner R (1995) Permanent presence of grazing-resistant bacteria in a hypertrophic lake. Appl Environ Microbiol 61:3457-3459

Strom SL (2000) Bacterivory: interactions between bacteria and their grazers. In: Kirchman DL (ed) Microbial ecology of the oceans. Wiley-Liss, New York, p 351-386

Suzuki MT, Giovannoni SJ (1996) Bias caused by template annealing in the amplification of mixtures of $16 \mathrm{~s}$ rRNA genes by PCR. Appl Environ Microbiol 62:625-630

Van Hannen EJ, Zwart G, van Agterveld MP, Gons HJ, Ebert J, Laanbroek HJ (1999) Changes in bacterial and eukaryotic community structure after mass lysis of filamentous cyanobacteria associated with viruses. Appl Environ Microbiol 65:795-801

Von Wintzingerode F, Göbel UB, Stackebrandt E (1997) Determination of microbial diversity in environmental samples-pitfalls of PCR-based rRNA analysis. FEMS Microbiol Rev 21:213-229

Wagner M, Amann R, Lemmer H, Schleifer KH (1993) Probing activated sludge with oligonucleotides specific for proteobacteria: inadequacy of culture-dependent methods for describing microbial community structure. Appl Environ Microbiol 59:1520-1525

Submitted: November 13, 2002; Accepted: March 2, 2003

Proofs received from author(s): April 22, 2003 